\title{
The organization and expression of a maize ribosomal protein gene family
}

\author{
John C. Larkin, ${ }^{1}$ John P. Hunsperger, David Culley, ${ }^{2}$ Irwin Rubenstein, and Carolyn D. Silflow \\ Department of Genetics and Cell Biology and Plant Molecular Genetics Institute, University of Minnesota, St. Paul, \\ Minnesota 55108-1095 USA
}

\begin{abstract}
We have isolated several Zea mays cDNAs encoding the 40S subunit ribosomal protein S14. In maize, this ribosomal protein is encoded by a small multigene family, at least three members of which are expressed. S14 transcript levels are highest in mitotically active tissues, such as seedling shoot, developing endosperm, and tassel primordia, and lowest in tissues with little cell division, such as mature leaf and root. Very little S14 RNA is present in pollen, suggesting that translation of pollen mRNAs during pollen germination uses preformed ribosomes. During kernel development, the highest levels of S14 transcripts in endosperm tissue are found at 10-12 days postpollination; S14 RNA levels decline continuously from this point onward. The period of maximal expression of the S14 ribosomal protein gene appears to precede the onset of storage protein synthesis and does not correlate with the reported times of increased nucleolar volume or genome amplification.
\end{abstract}

[Key Words: Zea mays; ribosomal protein S14; endosperm development]

Received November 7, 1988; revised version accepted February 8, 1989.

Protein synthesis plays a central role in cellular metabolism, and it is well established that the synthesis of the protein and RNA components of ribosomes is tightly coupled to the rate of cell proliferation in a wide variety of organisms. The regulation of eukaryotic ribosomal protein synthesis occurs at many different levels of gene expression, including transcription, mRNA processing, translation, and protein turnover, although all of these mechanisms do not apply in every organism or cell type (for review, see Fried and Warner 1984; Meyuhas 1984). Virtually without exception, the 70-80 cytosolic ribosomal proteins are coordinately regulated. During the development of multicellular organisms, protein synthesis requirements vary greatly (Davidson 1976), and developmental modulation of ribosomal protein gene expression has been observed in a number of instances (Hallberg and Smith 1975; La Marca and Wassarman 1979; Santon and Pelligrini 1980; Ramagopal and Ennis 1982). For example, Xenopus embryos depend on maternal ribosomes synthesized during oogenesis until well after gastrulation (Pierandrei-Amaldi et al. 1982; Baum and Wormington 1985). Mammalian oocytes store fewer ribosomes during oogenesis, and the synthesis of ribosomal proteins in the embryo begins almost immediately after fertilization, as early as the eight-cell stage in mouse (La Marca and Wassarman 1979; Piko and Clegg 1982). Thus, different organisms regulate the synthesis of ribosomal proteins in accord with the protein synthesis requirements of their developmental strategies, which may differ greatly.

'Current addresses: Department of Biochemistry, University of Minnesota, St. Paul, Minnesota 55108-1095 USA.; ${ }^{2}$ Department of Genetics and Cell Biology, Washington State University, Pullman, Washington 99163-6420 USA.
In contrast to the wealth of information that has accumulated about yeast and animal ribosomal protein genes in the past several years, little is known about the organization or expression of plant ribosomal protein genes. In the only detailed molecular analysis of plant ribosomal protein gene expression to date, Gantt and Key $(1983,1985)$ have demonstrated an eightfold coordinate induction of soybean ribosomal protein mRNAs after treatment of hypocotyl sections with the synthetic auxin 2,4-dichlorophenoxyacetic acid (2,4-D). The isolation of a rice ribosomal protein genomic clone has also been reported (Bhargava and Padayatty 1985).

As an initial approach to understanding the role of ribosome synthesis in plant growth and development, we have isolated several Zea mays cDNA clones that encode the 40S subunit ribosomal protein S14 (Larkin and Woolford 1983; Chen et al. 1986). The sequence of this ribosomal protein is highly conserved among yeast, mammals, and maize (Chen et al. 1986; Larkin et al. 1987; this study). The maize S14 ribosomal protein is encoded by a small multigene family with a minimum of three to six members, at least three of which are expressed. S14 transcript levels differ greatly among different maize tissues and organs, demonstrating that transcript levels of this ribosomal protein gene are modulated developmentally in maize.

\section{Results}

Isolation of Z. mays $c D N A$ clones homologous to the yeast S14 gene

The 40S subunit ribosomal protein S14, encoded in yeast by the CRY1 gene, has been highly conserved throughout eukaryotic evolution (Chen et al. 1986; 
Larkin et al. 1987). Therefore, this yeast gene seemed likely to be an effective hybridization probe for the isolation of a maize ribosomal protein cDNA. Initially, a cDNA library constructed from a black Mexican sweet corn (BMS) tissue-culture line (Sheridan 1975, 1982; Green 1977) was screened with a yeast $C R Y 1$ probe (see Materials and methods), and three positive clones were identified, which were designated $\mathrm{MCH} 1, \mathrm{MCH} 2$, and MCH3 (for maize $C R Y 1$ homolog). Restriction endonuclease mapping suggested that the clones fell into two classes, with $\mathrm{MCH} 1$ representing one class and $\mathrm{MCH} 2$ and $\mathrm{MCH} 3$ representing the other (Fig. 1). The nucleotide sequence of one member of each class $(\mathrm{MCH}$ and MCH2) was determined (Fig. 2A). Each cDNA contains an open reading frame that could code for a protein with an amino acid sequence extremely similar to the sequences of the yeast and mammalian S14 ribosomal proteins (Fig. 2B, see below). Sixty-seven nucleotide differences occur between the putative coding regions of the two maize cDNAs, only four of which result in amino acid substitutions. $\mathrm{MCH}$ also contains a three-nucleotide deletion relative to $\mathrm{MCH} 2$, which removes the glycine codon at position 3 in the predicted amino acid sequence of the $\mathrm{MCH} 1$ protein. The $3^{\prime}$-noncoding regions are completely divergent (Fig. 2A). The $\mathrm{MCH} 1$ and $\mathrm{MCH} 2 \mathrm{cDNAs}$ clearly represent the mRNA products of different genes.

When the amino acid alignment shown in Figure $2 B$ is used and excluding gaps are introduced to maintain sequence alignment, $77 \%$ of the amino acids (105 of 137) are identical between $\mathrm{MCHl}$ and the yeast S14 ribosomal protein (Larkin et al. 1987), and 88\% (129 of 147) of the amino acids are identical between $\mathrm{MCHl}$ and the CHO cell S14 ribosomal protein (Rhoads and Roufa 1985). The predicted MCH2 gene product is slightly less conserved relative to the $\mathrm{CHO}$ cell and yeast proteins ( 76 and $87 \%$ amino acid identity, respectively). Many of the amino acid differences between these sequences represent conservative substitutions. Two gaps must be inserted into the $\mathrm{MCHl}$ sequence and 1 gap must be inserted into the mammalian sequence to maintain the alignment shown in Figure 2B, whereas 12 gaps must be inserted into the yeast sequence to maintain alignment with MCH1. As noted above, one gap must be introduced into the $\mathrm{MCH} 2$ sequence to maintain alignment with $\mathrm{MCH}$. All of these gaps occur near the amino termini of the protein sequences. Indeed, the similarity between any pair of these amino acid sequences is substantially greater if the comparisons are restricted to the portion of the proteins from the valine residue at position 25 in $\mathrm{MCH}$ to the carboxyl termini, suggesting that the amino-terminal portion of this protein is under less selective pressure than the rest of the protein. The high degree of sequence similarity between the predicted amino acid sequences of the $\mathrm{MCH} 1$ and $\mathrm{MCH} 2$ gene products and the yeast and $\mathrm{CHO}$ cell $\mathrm{S} 14$ ribosomal proteins indicates that $\mathrm{MCH} 1$ and $\mathrm{MCH} 2$ are derived from two different genes encoding the maize homolog(s) of the S14 ribosomal protein. For this reason, we will refer to the gene family represented by these cDNAs as the
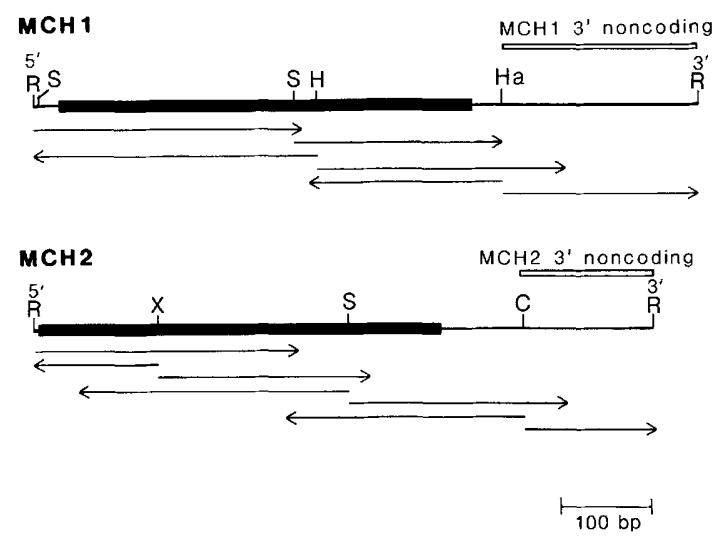

Figure 1. Restriction maps and sequencing strategies of the S14 cDNA clones MCH1 and MCH2. (R) EcoRI; (S) Sst $;$; H HindIII; (Ha) HaeIII; (X) XhoII; (C) ClaI. The putative coding region of each cDNA is indicated by a solid bar. The $3^{\prime}$-noncoding region probes used for the experiments described in Figs. 4 and 7 are indicated by open bars above the restriction maps.

maize S14 gene family. Because individual members of the gene family are probably represented by multiple cDNA clones in our collection (see below) and only two of the cDNAs have been sequenced, we will continue to refer to individual clones by their $\mathrm{MCH}$ designation.

There are no stop codons located in either cDNA sequence upstream of the methionine codons that we have assumed are the initiation codons of $\mathrm{MCH} 1$ and $\mathrm{MCH} 2$. Thus, we cannot rule out the possibility that the proteins encoded by these cDNAs are initiated upstream from the $5^{\prime}$ ends of the cDNA clones. However, we believe that this is unlikely because these cDNA clones hybridize to an 800-nucleotide transcript on RNA blots (data not shown). The sequence of the MCH1 cDNA is 688 nucleotides in length, excluding the poly(A) tail. This clone must be close to full length if we assume that the poly(A) tail is $\sim 100$ nucleotides long. We also note that the proteins predicted on the assumption that we have identified the initiator methionine are very similar in length to the mammalian S14 ribosomal proteins.

The maize S14 ribosomal protein is encoded by a small multigene family with at least three expressed members

When the $\mathrm{MCH} 1$ and $\mathrm{MCH} 2 \mathrm{cDNAs}$ were used to probe Southern blots of maize genomic DNA, it was apparent that the maize S14 ribosomal protein is encoded by a small multigene family (Fig. 3). Under our hybridization conditions, $\mathrm{MCH} 1$ hybridizes to between five and eight restriction fragments in each digest shown (Fig. 3). The $\mathrm{MCH} 2$ cDNA hybridizes to fewer sequences; three or four restriction fragments hybridize strongly in each lane (Fig. 3). On long exposures (not shown), it is apparent that most of the restriction fragments detected by $\mathrm{MCH} 1$ are also detected by $\mathrm{MCH} 2$, and vice versa. From these data, in conjunction with the cDNA cross-hybridization experiments presented below, we estimate that the S14 ribosomal protein is encoded by a minimum of three to six different genes and/or pseudogenes. 
Larkin et al.
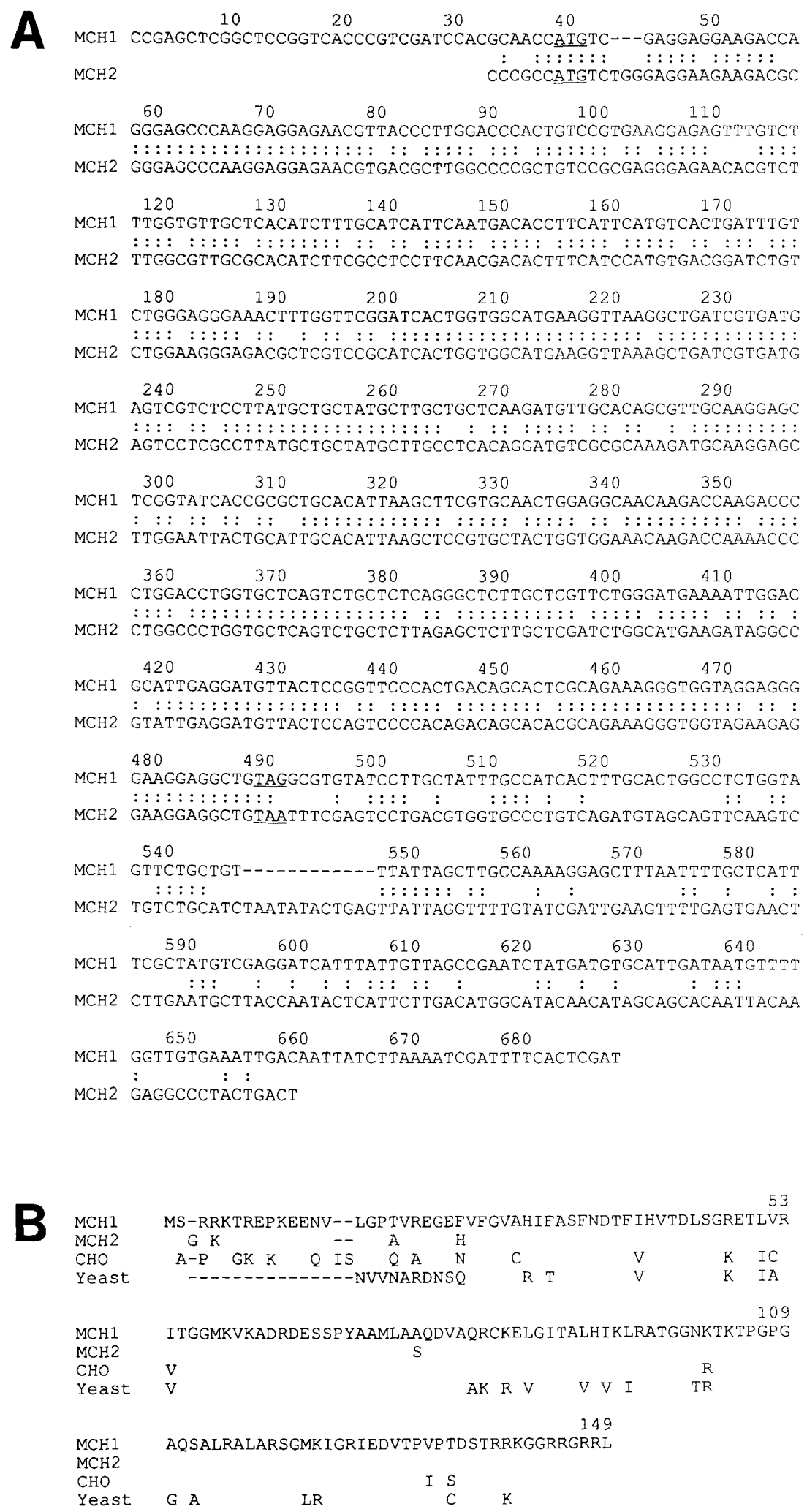

Figure 2. Nucleic acid and deduced amino acid sequences of $\mathrm{MCH} 1$ and $\mathrm{MCH} 2$. $(A)$ Comparision of the nucleotide sequences of $\mathrm{MCH} 1$ and $\mathrm{MCH} 2$. The sequence of $\mathrm{MCH} 1$ is terminated by $\sim 70$ adenylate residues. The sequence of $\mathrm{MCH} 2$ is terminated by $\sim 50$ adenylate residues. $(B)$ Comparision of the deduced amino acid sequences of MCH1 and MCH2 with the deduced amino acid sequences of the yeast (Larkin et al. 1987) and CHO cell (Rhoads and Roufa 1985) S14 ribosomal proteins. Note that the deduced sequence of the human protein is identical to that of the CHO cell protein (Rhoads et al. 1986). Both the nucleic acid and amino acid sequences are numbered relative to the sequence of the $\mathrm{MCH} 1 \mathrm{cDNA}$. 


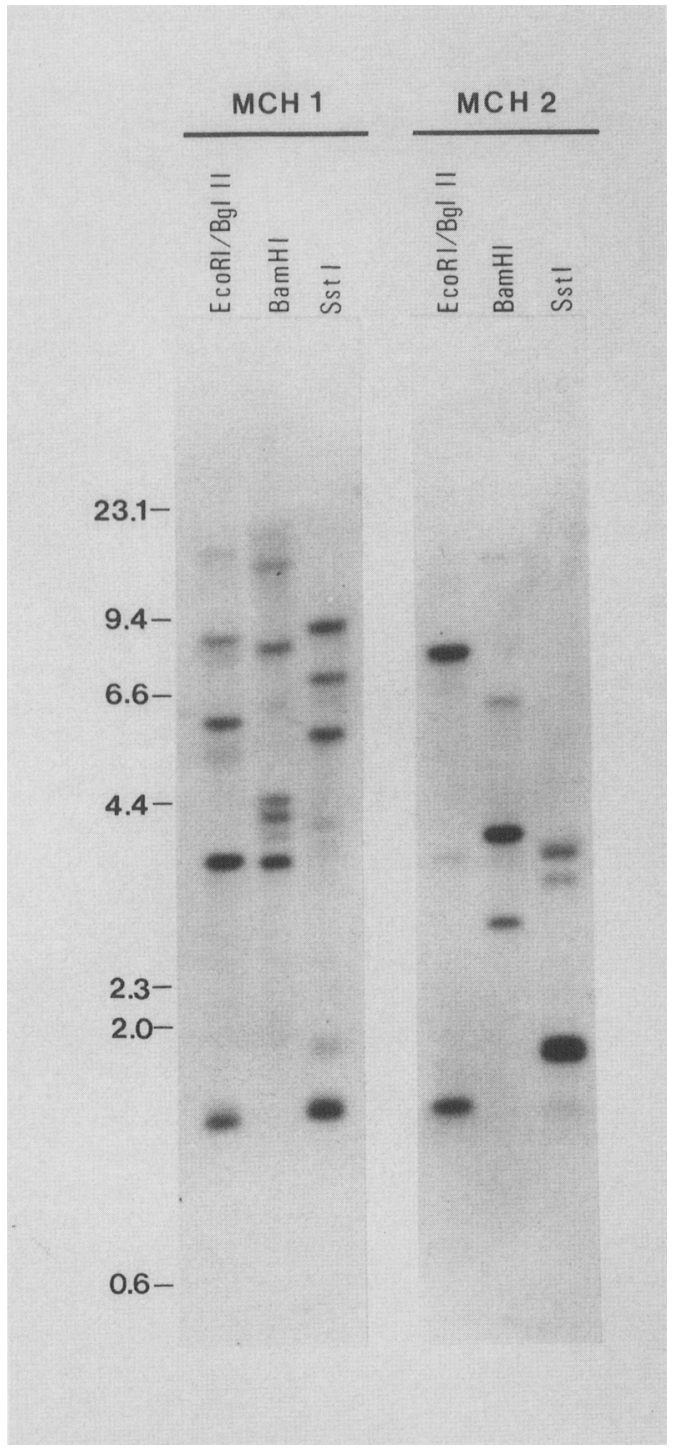

Figure 3. Genomic Southern blots of genomic DNA from the maize inbred A188 digested with various restriction enzymes and probed with the maize S14 ribosomal protein cDNAs $\mathrm{MCH} 1$ and $\mathrm{MCH} 2$. Twenty micrograms of A188 genomic DNA was digested with either EcoRI and BgIII (double digest), BamHI, or SstI and subjected to electrophoresis on a $0.8 \%$ agarose gel. An EcoRI-BgIII double digest was used because either of these enzymes alone produced a small number of poorly resolved bands larger than $10 \mathrm{~kb}$. The $\mathrm{MCH} 1$ probe used was the 5' EcoRI-HaeIII fragment containing the S14-coding region. The $\mathrm{MCH} 2$ probe used was the $5^{\prime}$ EcoRI-ClaI fragment containing the S14-coding region.

Because many mammalian ribosomal protein gene families contain large numbers $(7-20)$ of pseudogenes and only a single expressed copy (Dudov and Perry 1984; Wiedemann and Perry 1984; Wagner and Perry 1985|, we were interested in estimating how many S14 gene copies were expressed in maize. Nine additional cDNA clones were isolated from a cDNA library constructed from 8-day postpollination endosperm RNA of the A188 inbred line (J. Hunsperger, D. Culley, I. Rubentein, and

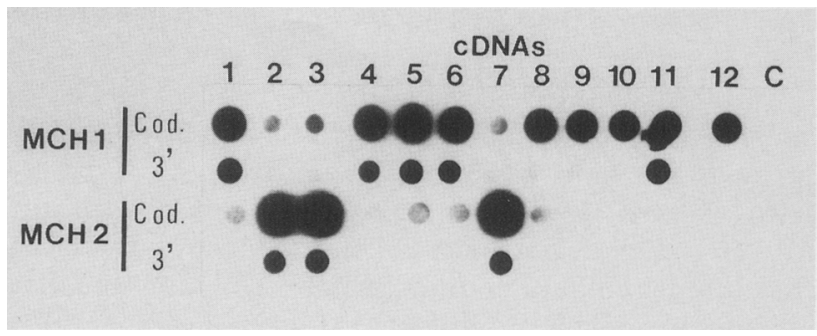

Figure 4. Hybridization of $\mathrm{MCH}$ cDNAs with $\mathrm{MCH}$ - and $\mathrm{MCH} 2$-coding and 3 '-noncoding probes demonstrates the existence of at least three different classes of S14 transcript in maize. DNA dot blots of the 12 maize S14 cDNAs (MCH1MCH12) and a control plasmid (BlueScribe M13 + vector DNA) were hybridized with coding region and 3 '-noncoding region probes derived from the $\mathrm{MCH} 1$ and $\mathrm{MCH} 2 \mathrm{cDNAs}$. The restriction fragments used as probes were the $5^{\prime}$ EcoRI-HaeIII fragment of MCH1 (MCH1 coding), the 3' EcoRI-HaeIII fragment of $\mathrm{MCH1}$ (MCH1 3' -noncoding), the 5' EcoRI-ClaI fragment of $\mathrm{MCH} 2$ (MCH2 coding), and the $3^{\prime}$ EcoRI-ClaI fragment of $\mathrm{MCH} 2$ (MCH2 3'-noncoding).

M. Brenner, unpubl.). These nine cDNA clones will be referred to as $\mathrm{MCH} 4-\mathrm{MCH} 12$. Preliminary sequencing results for $\mathrm{MCH} 10-\mathrm{MCH} 12$ confirm that these cDNAs represent $\mathrm{S} 14$ gene family transcripts.

Because cDNA synthesis in both of the cDNA libraries used in this work was primed from oligodeoxythymidine-tailed plasmid vectors, all cDNA clones from either library should contain the $3^{\prime}$ end sequences of the corresponding mRNA. Thus, $3^{\prime}$-noncoding region probes from $\mathrm{MCH} 1$ and $\mathrm{MCH} 2$ can be used to discriminate among the cDNA clones we have isolated. DNA dot blots of these nine cDNAs and the three cDNAs isolated previously were probed under high stringency conditions with an MCH1-coding region probe (the $5^{\prime}$ EcoRIHaeIII fragment, see Fig. 1), a $3^{\prime}$-noncoding region probe from $\mathrm{MCHl}$ (the 3' HaeIII-EcoRI fragment, see Fig. 1), an $\mathrm{MCH} 2$-coding region probe (the 5' EcoRI-Clal fragment, see Fig. 1), and a $3^{\prime}$-noncoding region probe from MCH2 (the 3' ClaI-EcoRI fragment, see Fig. 1). The 12 maize S14 cDNAs fall into three classes based on their hybridization patterns with these probes (Fig. 4). The first class ( $\mathrm{MCH}, \mathrm{MCH} 4, \mathrm{MCH} 5, \mathrm{MCH} 6$, and $\mathrm{MCH} 11$ ) consists of cDNAs that hybridize strongly to both the $\mathrm{MCH} 1$-coding probe and the $\mathrm{MCH} 13^{\prime}$-noncoding probe, hybridize weakly with the $\mathrm{MCH} 2$-coding probe, and do not hybridize with the $\mathrm{MCH} 23^{\prime}$-noncoding probe. All five of these cDNAs hybridize equally well with both the MCH1-noncoding and -coding probes, and all five contain two SstI sites and one HindIII site in locations apparently identical to the restriction map of $\mathrm{MCH}$ shown in Figure 1. These clones are likely to be derived from the same gene as $\mathrm{MCH} 1$.

The second class ( $\mathrm{MCH} 2, \mathrm{MCH} 3$, and $\mathrm{MCH} 7$ ) consists of $\mathrm{cDNAs}$ hybridizing strongly to the $\mathrm{MCH} 2$-coding and $3^{\prime}$-noncoding probes, weakly to the $\mathrm{MCH}$-coding region probe, and not at all to the MCH1 $3^{\prime}$-noncoding probe. MCH3 and MCH7 have no HindIII site and a single SstI site, consistent with the $\mathrm{MCH} 2$ restriction map (Fig. 
1A). It is likely that $\mathrm{MCH} 2, \mathrm{MCH} 3$, and $\mathrm{MCH} 7$ are derived from transcripts of the same $\mathrm{S} 14$ gene.

The third class ( $\mathrm{MCH} 8, \mathrm{MCH} 9, \mathrm{MCH} 10$, and $\mathrm{MCH} 12$ ) consists of clones that do not hybridize with either $3^{\prime}$ noncoding region probe and hybridize more strongly with the MCH1-coding region probe than with the $\mathrm{MCH} 2$-coding region probe. Unlike $\mathrm{MCH} 1$ or $\mathrm{MCH} 2$, these clones contain no internal SstI sites, although they all contain a single HindIII site. All four of these cDNAs are approximately the same length as $\mathrm{MCH1}$, and preliminary sequencing of the $5^{\prime}$ ends of $\mathrm{MCH1O}$ and MCH12 indicates that these two cDNAs both start 25 nucleotides upstream of the S14 ATG codon. Thus, it is unlikely that these four cDNAs fail to hybridize with the two 3 -noncoding region probes due to the use of an earlier polyadenylation site. $\mathrm{MCH} 8, \mathrm{MCH} 9, \mathrm{MCH} 10$, and $\mathrm{MCH} 12$ appear to represent the products of one or more additional expressed copies of the $\mathrm{S} 14$ gene family. From these data, we conclude that a minimum of three members of the maize S14 ribosomal protein gene family are expressed in maize endosperm.

\section{Levels of S14 mRNA in developing endosperm and other organs}

We were interested particularly in analyzing the expression of this ribosomal protein gene family in developing endosperm. This tissue synthesizes large quantities of storage proteins and thus has a requirement for high levels of protein synthesis. The relative levels of S14 transcript were quantitated by hybridizing an $\mathrm{MCH} 1$ cDNA probe to RNA dot blots of total RNA isolated at different times during endosperm development. Correction for measurement and loading errors between RNA samples was achieved by normalizing each sample to the signal obtained by hybridization with an rDNA probe (see Materials and methods). The results of this analysis are presented in Figure 5. A distinct peak of S14 gene expression was detected by the $\mathrm{MCH} 1$ probe in developing endosperm 10-12 days after pollination. A qualitatively identical peak in S14 transcript levels was observed upon probing RNA blots of poly(A) ${ }^{+}$RNA from developing endosperm with the $\mathrm{MCHl}$ probe (data not shown), demonstrating that the observed pattern of transcript accumulation is not an artifact of normalizing to rRNA levels. For comparison, a cDNA clone for the $10-\mathrm{kD}$ methionine-rich zein-associated protein gene (10 kD ZAP, Rubenstein and Geraghty 1986; Kirihara et al. 1988) was hybridized to the same endosperm RNA samples; this probe provides a marker for the onset of storage protein synthesis (Fig. 5). The pattern of transcript accumulation exhibited by the $10-\mathrm{kD}$ ZAP gene is quite different from the S14 pattern; the 10-kD ZAP transcript is present at low levels prior to 12 days after pollination and begins to rise rapidly after 16 days postpollination (note the change in scale for the $10-\mathrm{kD}$ ZAP data).

We also have examined the expression of the S14 ribosomal protein gene in other organs and tissues. Data are presented in Figure 6 for etiolated seedling shoot and

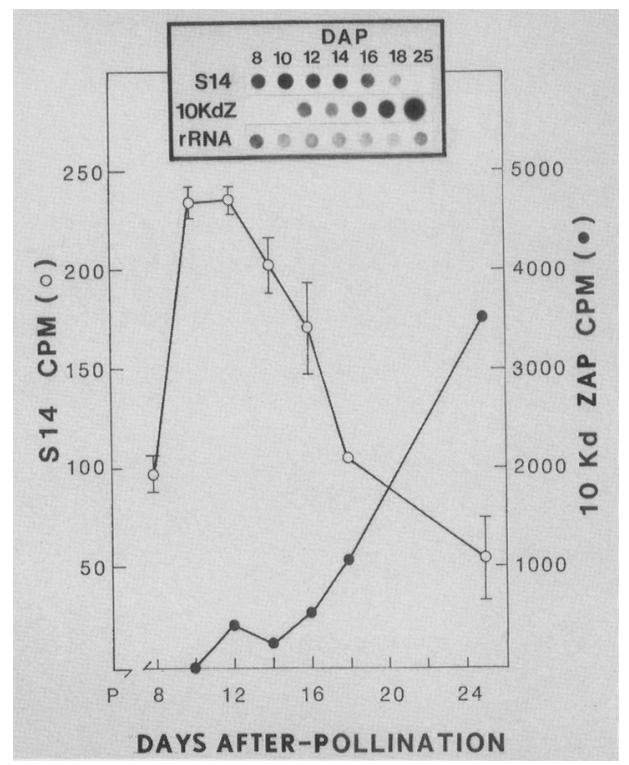

Figure 5. RNA dot-blot analysis of S14 transcript levels during endosperm development. Two micrograms of total RNA were analyzed per dot, and all samples were analyzed in duplicate. After hybridization, the dots were excised and counted in a scintillation counter. All samples were normalized to the rRNA probe signal to minimize loading errors. The probes used were the S14 cDNA clone MCHI, a 10-kD ZAP cDNA (Kirihara et al. 1988), and an EcoRI fragment containing the entire rDNA repeat (McMullen et al. 1986). Note that the $10-\mathrm{kD}$ ZAP data are presented on a different scale from the S14 data.

root; for stem, leaf, root, and tassel primordia from 4week-old field-grown plants; and for pollen. The endosperm sample 12 days after pollination is included for reference; this value is directly comparable, as the endosperm and tissue samples were hybridized together in the same bag. As additional controls, the results of hybridizations with a maize $\beta$-tubulin probe and a glutamine synthetase cDNA are shown. S14 transcript levels vary $>10$-fold among the various organs and tissues examined. The highest levels of S14 expression were found in endosperm 12 days after pollination, whereas the lowest were found in pollen and mature leaf.

mRNA levels of two copies of the maize S14 gene are coordinately regulated

We have used 3 '-noncoding region probes from the $\mathrm{MCH} 1$ and $\mathrm{MCH} 2$ clones to examine the expression of different members of this gene family. As discussed above, these probes hybridize to mutually exclusive subsets of the maize S14 gene family. The two 3'-noncoding probes have been hybridized to RNA blots, and the same filters have been stripped of probe and rehybridized with the $\beta$-tubulin probe and glutamine synthetase probe (Fig. 7). The transcripts recognized by the two 3 '-noncoding probes show identical patterns of expression, suggesting that the $\mathrm{MCH} 1$ and $\mathrm{MCH} 2$ homologous subclasses of S14 mRNA are coordinately regulated. 


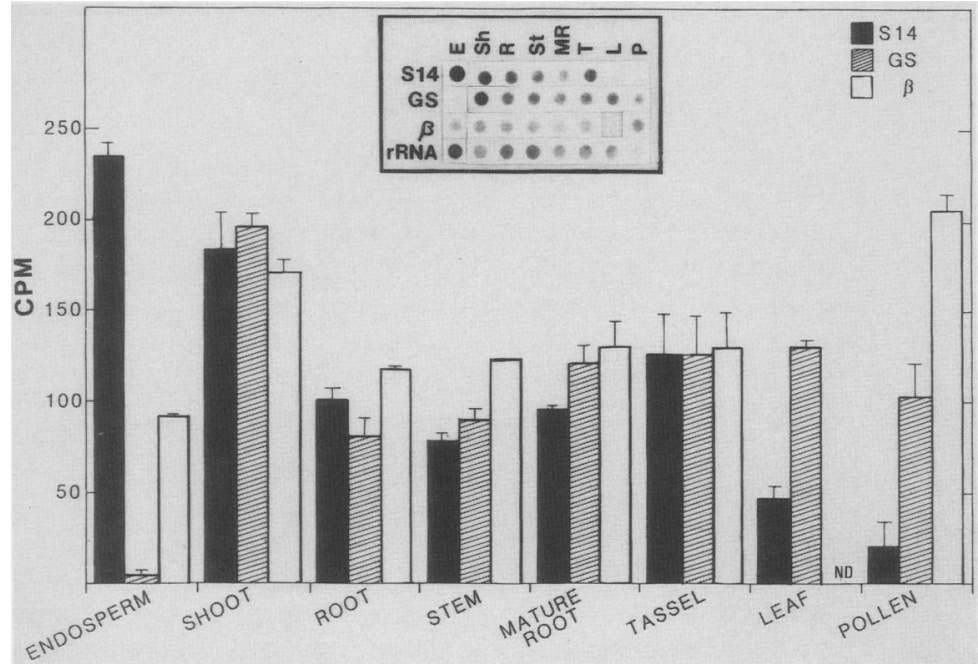

Figure 6. RNA dot-blot analysis of S14 transcript levels in various tissues and organs. RNA dot-blot analysis was carried out exactly as described for Fig. 5. RNA samples were as follows: (Endosperm) endosperm 12 days after pollination; (shoot) 6-day-old seedling shoot; (root) 6-day-old seedling root; (stem) stem from 4week-old plants; (mature root) root from 4-week-old plants; (tassel) tassel primordia from 4-week-old plants; (leaf) fully expanded leaves from 4-week-old plants; (pollen) mature pollen. Probes used were the entire insert of the S14 cDNA clone $\mathrm{MCHl}$, a maize glutamine synthetase (GS) cDNA clone (Snustad et al. 1988), and the entire insert of a maize $\beta$-tubulin cDNA clone (P. Hussey, pers. comm.). (ND) Not determined.

\section{Discussion}

The data presented here demonstrate that the maize homolog of the 40S subunit ribosomal protein S14 is encoded by a small multigene family containing a minimum of three to six members. Although we have not ruled out the possibility that some members of the gene family are pseudogenes, it is clear that at least three members of the maize S14 gene family are expressed. No other eukaryotic organism has been found to express more than two members of a ribosomal protein gene family, although mammalian ribosomal protein gene families often contain many pseudogenes (Dudov and Perry 1984; Wiedemann and Perry 1984; Wagner and Perry 1985).

Why does maize maintain such a large ribosomal protein multigene family? One explanation is that at some stage in the maize life cycle, more of the S14 ribosomal protein is required than can be provided by a single gene. Because we have determined relative rather than absolute transcript abundances, our data do not directly address this hypothesis. However, the data presented in Figure 5 indicate that the highest S14 transcript levels observed are much lower than those of the 10-kD ZAP, a relatively minor storage protein encoded by a single gene (Kirihara et al. 1988). Another explanation for the maintenance of a multigene family is that different copies of the gene are regulated differently, allowing the plant to control the level of the S14 gene product independently in different cell types or developmental stages. Our data provide no support for this hypothesis, as transcript levels of the two members of the gene family whose expression we have examined appear to be regulated identically (Fig. 7). However, we cannot rule out the possibility that some other member of the gene family exhibits a different pattern of expression. Possibly, the gene products of different members of the family could have different functions. Although there is no evidence for functionally different subclasses of ribosomes in most organisms, in Plasmodium, stage-specific rRNAs have been reported recently (Gunderson et al. 1987). Al- though the existence of functionally distinct forms of the highly conserved S14 ribosomal protein seems unlikely, this hypothesis cannot be ruled out. An alternative explanation is provided by the recent data of $\mathrm{He}$ lentjaris et al. (1988), demonstrating that large contiguous regions of the maize genome are duplicated; perhaps, some of the gene copies lie within the duplicated regions. At present, the large size of the S14 gene family in maize remains an intriguing enigma. It will be interesting to examine the genes encoding other maize ribosomal proteins to see whether the $\mathrm{S} 14$ gene family is typical or exceptional.

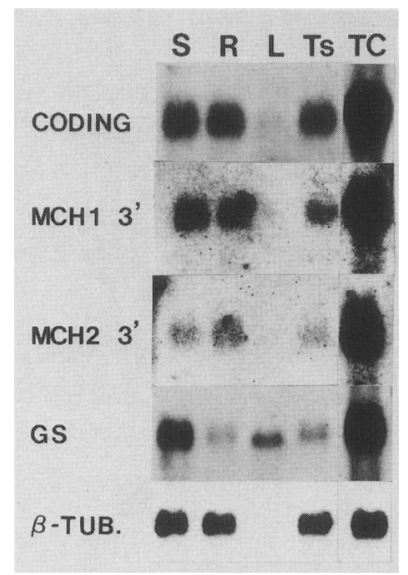

Figure 7. Northern blots of RNA from various tissues and organs probed with $3^{\prime}$-noncoding region probes (see Fig. 1) from the two S14 cDNAs $\mathrm{MCH} 1$ and $\mathrm{MCH} 2$. One microgram of poly(A) ${ }^{+}$RNA was loaded per lane. RNA samples were as follows: (S) seedling shoot, 6 day; (R) seedling root, 6 day; $(\mathrm{L})$ fully expanded leaf, 4-week; (Ts) tassel primordia, 4 week; (TC) black Mexican tissue culture cells. Probes used were the entire insert of MCHl (coding), the 3' HaeIII-EcoRI fragment of $\mathrm{MCH} 1\left(\mathrm{MCHl} 3^{\prime}\right)$, the $3^{\prime} \mathrm{ClaI}-E c o$ RI fragment of $\mathrm{MCH} 2$ $\left(\mathrm{MCH} 23^{\prime}\right)$, the entire insert from a maize glutamine synthetase cDNA (GS) (Snustad et al. 1988), and the entire insert from a maize $\beta$-tubulin cDNA ( $\beta$-tub.) (P. Hussey, pers. comm.). 
Our results demonstrate clearly that transcript levels of the S14 gene family are modulated developmentally in maize (Figs. 6 and 7). Among the different tissues and organs examined from various stages of the maize life cycle, S14 transcript levels varied by more than 10 -fold. In general, S14 transcript levels were highest in tissues with high rates of cell division such as developing endosperm, 6-day-old seedling shoot, and tassel primordia. A similar coupling of cell proliferation and ribosomal protein gene expression has been observed in yeast (Kief and Warner 1981) and in mammalian systems (Faliks and Meyuhas 1982; Geyer et al. 1982; Tushinski and Warner 1982). Two different S14 gene family members exhibit similar patterns of transcript accumulation, suggesting that they are coordinately regulated. The mechanism used to achieve this coordinate regulation is unknown; in other organisms, both transcriptional and post-transcriptional mechanisms have been identified that coordinate the expresion of ribosomal protein genes (Fried and Warner 1984; Meyuhas 1984). The data in Figure 7 suggest that S14 transcript levels are quite high in RNA isolated from tissue culture cells. This result is intriguing in light of the reports by Gantt and Key (1983, 1985) that treatment of soybean hypocotyls with the synthetic auxin 2,4-D substantially increases ribosomal protein mRNA levels, because the maize tissue-culture cells were propagated in media containing high levels of 2,4-D.

We also find that S14 transcript levels are temporally regulated during endosperm development, varying nearly fivefold during the period from $8-25$ days after pollination, with a distinct peak in transcript levels 10-12 days after pollination (Fig. 5). Ribosomal protein gene expression during endosperm development was of particular interest for several reasons. First, this tissue accumulates large quantities of storage proteins and might be expected a priori to require a relatively high protein-synthesizing capacity (Soave and Salamini 1984). In addition, several unusual events during endosperm development suggest that this tissue is highly specialized (Fig. 8). Endosperm development commences with a phase of rapid cell division. The mitotic index reaches a maximum 8-10 days after pollination; by 22 days after pollination, virtually no cells in mitosis are observed (Duvik 1955; Kowles and Phillips 1985, 1988). Cell divisions cease first in the central region of the endosperm. However, DNA replication continues, and the cells in the central region become highly polytene (Phillips et al. 1983, 1985; Kowles and Phillips 1985). Cytological observations reveal that the nucleoli of these central cells increase dramatically in volume at this time as well, reaching a peak at 16-18 days after pollination (Phillips et al. 1983, 1985; Kowles and Phillips 1985). In other systems (Honjo and Roeder 1973), including plants (Chen et al. 1975; Guilfoyle et al. 1976), increased nucleolar size is often correlated with increased rRNA synthesis, although it is not known whether this correlation holds in maize endosperm.

The observed pattern of S14 transcript accumulation shows no correlation with the accumulation of storage protein mRNAs, time of DNA amplification, or nucleolar size in the central cells of the endosperm. S14 expression is correlated with the mitotic index (cf. Figs. 5 and 8). In retrospect, this is not surprising, given the overall correlation of S14 gene expression with mitotic activity noted above. S14 transcript levels are higher in endosperm than in any other tissue or organ examined, raising the possibility that this tissue produces large numbers of ribosomes in preparation for the onset of zein synthesis several days later. At the present time, the role of the large nucleoli in the central cells of maize endosperm 16-20 days after pollination is unclear.

The experiments described above address the expression pattern of the maize S14 gene at the level of transcript accumulation only. It is possible that the S14 protein shows a different pattern of expression; well-documented cases of translational control of ribosomal protein expression have been reported in other organisms (Fried and Warner 1984; Meyuhas 1984). Additional experiments will be necessary to confirm the expression pattern of the S14 protein.

Although we have examined the expression of only 1 of more than 70 proteins present in the $80 \mathrm{~S}$ eukaryotic ribosome, it seems likely that other maize ribosomal protein genes will have similar patterns of transcript accumulation. In all organisms examined to date, ribosomal protein genes have been found to be coordinately regulated at the level of transcript accumulation (Fried and Warner 1984; Meyuhas 1984). The high degree of

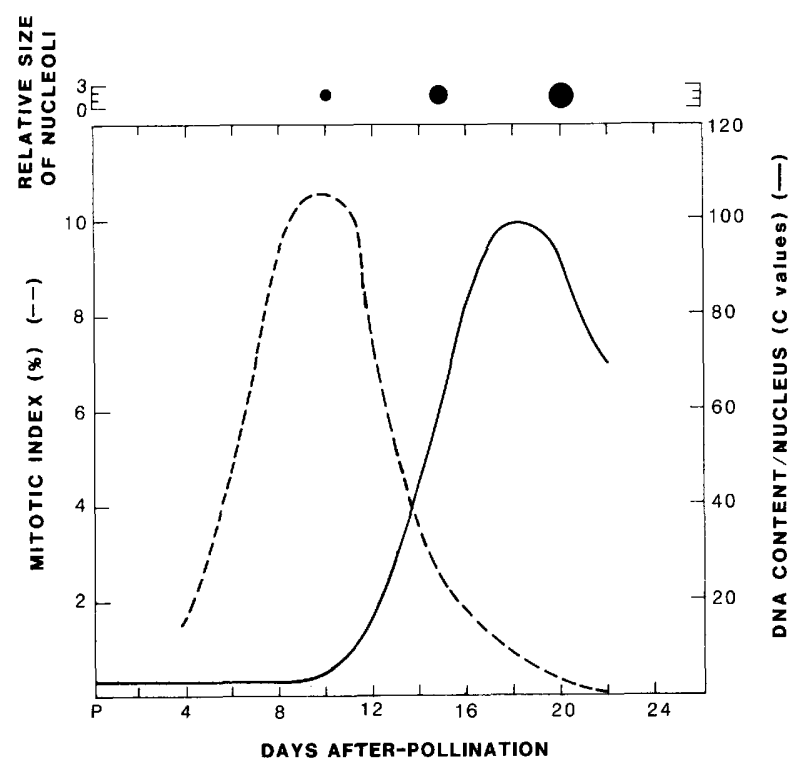

Figure 8. Summary of maize endosperm developmental events. The mitotic index illustration is based on the quantitative data of Kowles and Phillips (1985) and the detailed qualitative observations of Duvik (1955). The DNA content per nucleus in the central cells of developing maize (A188) endosperm is redrawn from the data of Kowles and Phillips (1985). The data on relative nucleolar size in the central region cells of developing endosperm (A188) are from R. Kowles (pers. comm.); these data are very similar to that reported by Phillips et al. (1983). 
sequence conservation of this protein throughout eukaryotic evolution strongly suggests that this protein is an important ribosomal component.

\section{Materials and methods}

\section{Maize stocks and cultures}

The BMS suspension cell culture line (Sheridan 1975, 1982; Green 1977) was obtained from C. E. Green and has been maintained in MS media (Murashige and Skoog 1962) supplemented with 2,4-D ( $2 \mathrm{mg} /$ liter), asparigine $(200 \mathrm{mg} /$ liter $)$, and sucrose $(2 \%)$. Seeds of the A188 inbred line were obtained from R.L. Phillips (University of Minnesota) and maintained by self or sibling pollinations. For the isolation of endosperm tissue used in these experiments, kernels were collected at the indicated times after pollination from plants grown in the field during the 1986 growing season. The endosperm was dissected free of embryo and nucellar tissue, and the tissue was immediately frozen in liquid nitrogen. Tassel primordia were isolated from 4-weekold A188 plants grown in the field in 1987. At this time, the tip of the eleventh leaf was just visible. The tassel primordia were $0.5-1.0 \mathrm{~cm}$ in length and were initiating spikelet-pair primordia at the time of isolation (Kiesselbach 1949; Cheng et al. 1983). Leaf, root, and stem tissue was also harvested from these 4-week-old plants. Seedling shoot and root tissue was obtained from 6-day-old dark grown A188 plants.

\section{Recombinant DNA methods and radioactive labeling of probes}

All recombinant DNA manipulations were performed using standard methods (Maniatis et al. 1982). Isolated restriction fragments and clones present in double-stranded DNA plasmid vectors were labeled by nick translation (Rigby et al. 1977). Single-stranded probes were generated by primer extension labeling of single-strand templates ( $\mathrm{Hu}$ and Messing 1982) derived from clones in the plasmid vectors pUC118 or pUCl19 (Vieira and Messing 1987) by using a synthetic primer (M13 hybridization primer, Amersham).

\section{Isolation and analysis of cDNA clones}

Two maize cDNA libraries were used in this work. The library used to obtain the first cDNA clones, termed BMS-3, was constructed from BMS suspension culture cell RNA in the vector pUC13. The library used for the isolation of additional cDNA clones was constructed in the vector BlueScribe $\mathrm{M} 13+$ iStrategene) from endosperm RNA from the A188 inbred 8 days after pollination (D. Culley, J. Hunsperger, P. Das, M. Brenner, and I. Rubenstein, unpubl.). Both libraries were constructed by priming cDNA synthesis with an oligo(dT)-tailed vector using a modification of the Okayama and Berg (1982) procedure.

To obtain the initial S14 cDNA clones, a 2.2-kb HindIII fragment containing the Saccharomyces cerevisiae CRY1 gene (Larkin and Woolford 1983) was used as a probe to screen the BMS cDNA library by the colony hybridization procedure of Gergen et al. (1979) under low stringency hybridization conditions $20 \%$ formamide, $6 \times$ SSPE, $1 \times$ Denhardt's solution, $0.1 \%$ SDS, $0.1 \mathrm{mg} / \mathrm{ml}$ calf thymus DNA, $20 \mu \mathrm{g} / \mathrm{ml}$ poly(A) at $35^{\circ} \mathrm{C}$ ) and washed four times for $15 \mathrm{~min}$ each with $2 \times$ SSPE, $0.2 \%$ SDS at $45^{\circ} \mathrm{C}\left[1 \times \mathrm{SSPE}\right.$ is $0.15 \mathrm{M} \mathrm{NaCl}, 0.01 \mathrm{M} \mathrm{NaH}_{2} \mathrm{PO}_{4}, 8$

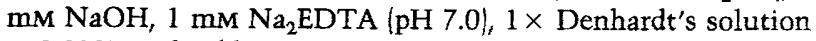
is $0.02 \%$ each of bovine serum albumin, Ficoll, and polyvinyl pyrrolidone|. These hybridization conditions were modified from those of Howley et al. (1979). Three clones were isolated from a total of 2500 colonies screened and are described in the text as $\mathrm{MCH} 1, \mathrm{MCH} 2$, and $\mathrm{MCH} 3$.

The cDNA clones $\mathrm{MCH} 4-\mathrm{MCH} 12$ were isolated by colony hybridization screening of the A188 endosperm cDNA library 8 days after pollination, using a mixture of the $\mathrm{MCH} 1$ and $\mathrm{MCH} 2$ insert EcoRI fragments labeled by nick translation (Rigby et al. $1977)$ as a probe. The prehybridization and hybridization were performed in $50 \%$ formamide, $5 \times$ SSPE and $1 \times$ Denhardt's, $0.1 \%$ SDS, and $0.1 \mathrm{mg} / \mathrm{ml}$ calf thymus DNA at $37^{\circ} \mathrm{C}$; the filters were washed four times in $2 \times \mathrm{SSPE}, 0.2 \%$ SDS at $50^{\circ} \mathrm{C}$. Nine clones were isolated from a total of 16,000 colonies screened.

\section{DNA sequence analysis}

Restriction fragments to be sequenced were subcloned into either pUCl18 or pUCl19 (Vieira and Messing 1987). Singlestrand templates were prepared as described by McMullen et al. (1986) and sequenced by the dideoxynucleotide chain termination method of Sanger et al. (1977), using $\left[\alpha^{-35}\right.$ S]dATP as the labeled nucleotide. As illustrated by the sequencing strategy shown in Figure 1, all sequence was determined on both strands, with the exception of a small portion of each clone in the 3 '-noncoding region.

\section{Genomic Southern blot analysis}

Maize genomic DNA was isolated from the shoots of 6-day-old A188 seedlings. Frozen tissue was powdered with a mortar and pestle on dry ice. The frozen powder was suspended in a buffer containing $0.1 \mathrm{M}$ Tris- $\mathrm{HCl}(\mathrm{pH} 8.0), 20 \mathrm{mM}$ EDTA, $0.6 \mathrm{M} \mathrm{NaCl}$, and $0.5 \%$ SDS at $60^{\circ} \mathrm{C}$. 2-Mercaptoethanol was added to $10 \mathrm{~mm}$. After shaking at $60^{\circ} \mathrm{C}$ for $10 \mathrm{~min}$, the solution was extracted with phenol-chloroform $\{1: 1\}$ and then with chloroform. To remove carbohydrates, the total sodium ion concentration of the aqueous phase was adjusted to $0.7 \mathrm{M}$ with $3 \mathrm{M} \mathrm{NaOAc}$ and hydrated; washed cellulose CF- 11 was added $(0.3 \mathrm{~g}$ dry weight of cellulose per $10 \mathrm{ml}$ of solution; Mozer 1980). The solution was swirled on ice for $15 \mathrm{~min}$, and the cellulose was removed by centrifugation. RNA was removed by lithium chloride precipitation. DNA was precipitated with ethanol and spooled two times.

Genomic DNA was digested with restriction enzymes, and $20 \mu \mathrm{g} /$ lane was subjected to electrophoresis through $0.8 \%$ agarose gels. The DNA was then transferred to a nylon filter (Genetran, Plasco Corp.) by the method of Southern (1975), with the modification that the transfer buffer was $1 \mathrm{M} \mathrm{NH}_{4} \mathrm{O}$ acetate, $0.2 \mathrm{~N} \mathrm{NaOH}$, as described by Rigaud et al. (1987). DNA blots were prehybridized and hybridized at $42^{\circ} \mathrm{C}$ in $50 \%$ formamide, $5 \times$ SSPE, $1 \times$ Denhardt's solution, $1 \%$ SDS, 0.1 $\mathrm{mg} / \mathrm{ml}$ calf thymus DNA, and $300 \mathrm{ng} / \mathrm{ml}$ pUCl18 singlestranded DNA. Filters were prehybridized for $4 \mathrm{hr}$, and hybridized for 36-40 hr. The filters were washed twice with $2 \times$ SSPE, $0.2 \%$ SDS for $15 \mathrm{~min}$ at $65^{\circ} \mathrm{C}$ and twice with $0.1 \times$ SSPE for 15 min at $65^{\circ} \mathrm{C}$, and exposed to X-ray film (Kodak X-AR or Dupont Cronex) with an intensifying screen. For the experiment shown in Figure 3, single-stranded plasmid probes generated from subclones in the vector pUC118 (Vieira and Messing 1987) of coding-region fragments from $\mathrm{MCH} 1 \quad 15^{\prime}$ EcoRI-HaeIII fragment) and $\mathrm{MCH} 2$ (5' EcoRI-ClaI fragment) were used as hybridization probes.

\section{DNA dot blots of cDNA clones}

One microgram of each cDNA clone in a plasmid vector (either pUC13 or Bluescribe $\mathrm{Ml} 3+$ | was denatured in $0.3 \mathrm{~N} \mathrm{NaOH}$ at $65^{\circ} \mathrm{C}$ for $10 \mathrm{~min}$, neutralized by the addition of an equal volume 
of $0.3 \mathrm{M}$ Tris $\mathrm{HCl}$ ( $\mathrm{pH} 7.5$ ), and diluted 20-fold with ice-cold $1 \mathrm{M}$ ammonium acetate. One tenth of the sample $(0.1 \mathrm{ml})$ was applied to a nitrocellulose filter that had been prewet in $10 \times$ SSPE, using a Schleicher and Schuell Minifold dot-blotting apparatus. After baking in vacuo at $80^{\circ} \mathrm{C}$ for $2 \mathrm{hr}$, the filter was prehybridized, hybridized, and washed as described for genomic Southern blot hybridization, with the exception that pUC118 single-stranded DNA was omitted from the hybridization. The probes were double-stranded DNA restriction fragments (see Fig. 4 legend) labeled by nick translation.

\section{RNA isolation and analysis}

Total RNA was isolated from frozen plant tissues hand-ground in a mortar and pestle by phenol-chloroform extraction and $\mathrm{CsCl}$ gradient centrifugation (Glisin et al. 1974), as described previously for the preparation of Chlamydomonas reinhardtii RNA (Schloss et al. 1984). Poly(A) ${ }^{+}$RNA was prepared by two cycles of oligo(dT)-cellulose chromatography, as described by Woolford et al. (1979). RNA samples were subjected to electrophoresis on denaturing formaldhyde gels, as described previously (Larkin and Woolford 1983; Last et al. 1984), and transferred to nylon filters (Nytran, Schleicher and Schuell). Prehybridization, hybridization, and washing conditions for RNA blots were identical to those used for DNA dot blots. The probes used for the experiment shown in Figure 7 were all primer extension-labeled single-stranded pUC118 or pUCl19 templates containing the inserts indicated in the figure legend in the orientation appropriate for hybridization to the corresponding mRNA.

RNA dot-blot analysis was performed as described by Schloss et al. (1984). Two micrograms of total RNA was analyzed per dot, and all samples were analyzed in duplicate. A standard dilution series of RNA was included in each hybridization to ensure that the samples fell within the linear range of the technique. As a control for measurement and loading errors among the RNA samples, a ribosomal DNA probe (see below) was hybridized with a 1000-fold dilution of each RNA sample. This dilution was necessary to bring the concentration of rRNA within the linear range of the assay. This dilution was done two independent times to minimize errors resulting from the dilution itself. All samples were normalized on the basis of the rDNA hybridization results. These corrected values are reported in Figures 5 and 6 . The probes used for the experiments shown in Figures 5 and 6 were all primer extension-labeled single-stranded pUC118 or pUC119 templates containing the inserts indicated in the figure legends in the orientation appropriate for hybridization to the corresponding mRNA, with the exception of the rDNA probe. This probe consisted of the plasmid pZmR1 (McMullen et al. 1986), containing the entire maize rDNA repeat, which had been labeled by nick translation.

\section{Acknowledgments}

We thank Dr. Richard Kowles for communicating unpublished results and for helpful discussions; Dr. Patrick Hussey, Dr. D. Peter Snustad, and Nandini Mendu for helpful discussions; Kris Kohn for the preparation of several figures; and Drs. John Woolford, Steve Gantt, and Perry Hackett for critical reading of the manuscript. The computer analysis of DNA sequence data was performed with the facilities and assistance of the University of Minnesota Molecular Biology Computing Center. J.C.L. was supported by an National Institutes of Health (NIH) Postdoctoral Fellowship. This work was also supported by a grant from the U.S. Department of Agriculture (85-CRCR-1-1754) to C.D.S. and by a grant from the NIH (GM-24756) to I.R.

\section{References}

Baum, E.Z. and W.M. Wormington. 1985. Coordinate expression of ribosomal protein genes during Xenopus develpoment. Dev. Biol. 126: 141-149.

Bhargava, A.K. and J.D. Padayatty. 1985. Cloning of rice DNA in lambda Charon 4 phage and identification of the gene for a ribosomal protein. Indian J. Biochem. Biophys. 22: 261267.

Chen, Y.M., C.-Y. Lin, H. Chang, T.J. Guilfoyle, and J.L. Key. 1975. Isolation and properties of nuclei from control and auxin-treated hypocotyl. Plant Physiol. 56: 78-82.

Chen, I-T., A. Dixit, D. D. Rhoads, and D. J. Roufa. 1986. Homologous ribosomal proteins in bacteria, yeast, and humans. Proc. Natl. Acad. Sci. 83: 6909-6911.

Cheng, P.C., R.I. Greyson, and D.B. Walden. 1983. Organ initiation and the development of unisexual flowers in the tassel and ear of Zea mays. Am. J. Bot. 70: 450-462.

Davidson, E. 1976. Gene activity in early development, 2 nd ed. Academic Press, New York.

Dudov, K.P. and R.P. Perry. 1984. The gene family encoding mouse ribosomal protein $\mathrm{L} 32$ contains a uniquely expressed intron-containing gene and an unmutated processed gene. Cell 37: 457-468.

Duvik, D. N. 1955. Cytoplasmic inclusions of the developing and mature maize endosperm. Am. I. Bot. 42: 717-725.

Faliks, D. and O. Meyuhas. 1982. Coordinate regulation of ribosomal protein mRNA levels in regenerating rat liver. Study with the corresponding mouse cloned cDNAs. Nucleic Acids Res. 10: 789-801.

Fried, H.M. and J.R. Warner. 1984. Organization and expression of eukaryotic ribosomal protein genes. In Recombinant DNA and cell proliferation (ed. G. Stein and J. Stein), pp. 169-192. Academic Press, New York.

Gantt, J.S. and J.L. Key. 1983. Auxin-induced changes in the level of translatable ribosomal protein messenger ribonucleic acids in soybean hypocotyl. Biochemistry 22: 41314139 .

- 1985. Coordinate expression of ribosomal protein mRNAs following Auxin treatment of soybean hypocotyls. J. Biol. Chem. 260: 6175-6181.

Gergen, J.P., R.H. Stern, and P.C. Wensink. 1979. Filter replicas and permanent collections of recombinant DNA plasmids. Nucleic Acids Res. 7: 2115-2136.

Geyer, P.K., O. Meyuhas, R.P. Perry, and L.F. Johnson. 1982. Regulation of ribosomal protein mRNA content and translation in growth-stimulated mouse fibroblasts. Mol. Cell Biol. 2: 685-693.

Glisin, V., R. Crkvenjakov, and C. Byus. 1974. Ribonucleic acid isolated by cesium chloride centrifugation. Biochemistry 13: $2633-2637$.

Green, C.E. 1977. Prospects for crop improvement in the field of cell culture. Hortic. Sci. 12: 131-134.

Guilfoyle, T.J., C.-Y. Lin., Y.M. Chen, R.T. Nagao, and J.L. Key. 1975. Enhancement of soybean RNA polymerase I by auxin. Proc. Natl. Acad. Sci. 72: 69-72.

Gunderson, J.H., M.L. Sogin, G. Wollett, M. Hollingdale, V.F. de la Cruz, A.P. Waters, and T.F. McCutchan. 1987. Structurally distinct, stage specific ribosomes occur in Plasmodium. Science 238: 933-937.

Hallberg, R.L. and D.C. Smith. 1975. Ribosomal protein synthesis in Xenopus laevis oocytes. Dev. Biol. 42: 40-52.

Helentjaris, T., D. Weber, and S. Wright. 1988. Identification of the genomic locations of duplicate nucleotide sequences in maize by analysis of restriction fragment length polymorphisms. Genetics 118: 353-363.

Honjo, T. and R.H. Reeder. 1973. Preferential transcription of 
Xenopus laevis ribosomal RNA in interspecies hybrids between X. laevis and X. mulleri. J. Mol. Biol. 80: 217.

Howley, P.M., M.A. Israel, M. Law, and M.A. Martin. 1979. A rapid method for detecting and mapping homology between heterologous DNAs. J. Biol. Chem. 254: 4876-4883.

$\mathrm{Hu}, \mathrm{N} . \mathrm{-T}$. and J. Messing. 1982. The making of strand-specific M13 probes. Gene 17: 271-277.

Kief, D.R. and J.R. Warner. 1981. Co-ordinated control of synthesis of ribosomal ribonucleic acid and ribosomal proteins during nutritional shift-up in Saccharomyces cerevisiae. Mol. Cell. Biol. 1: 1007-1015.

Kisselbach, T.A. 1949. The structure and reproduction of corn. Agricultural Experimental Station Research Bulletin 161. University of Nebraska Press, Lincoln, Nebraska.

Kirihara, J.A., J.P. Hunsperger, W.C. Mahoney, and J.W. Messing. 1988. Differential expression of a gene for a methionine-rich storage protein in maize. Mol. Gen. Genet. 211: 477-484.

Kowles, R.V. and R.L. Phillips. 1985. DNA amplification patterns in maize endosperm nuclei during kernel development. Proc. Natl. Acad. Sci. 82: 7010-7014.

_ 1988. Endosperm development in maize. Int. Rev. Cytol. 112: 97-136.

La Marca, M.J. and P.M. Wassarman. 1979. Program of early development in the mammal: Changes in absolute rates of synthesis of ribosomal proteins during oogenesis and early embryogenesis in the mouse. Dev. Biol. 73: 103-119.

Larkin, J.C. and J.L. Woolford, Jr. 1983. Molecular cloning and analysis of the CRY1 gene: A yeast ribosomal protein gene. Nucleic Acids Res. 11: 403-420.

Larkin, J.C., J.R. Thompson, and J.L. Woolford, Jr. 1987. Structure and expression of the Saccharomyces cerevisiae CRY1 gene: A highly conserved ribosomal protein gene. Mol. Cell. Biol. 7: 1764-1775.

Last, R.L., J.B. Stavenhagen, and J.L. Woolford, Jr. 1984. Isolation and characterization of the RNA2, RNA3, and RNA11 genes of Saccharomyces cerevisiae. Mol. Cell Biol. 4: 23962405.

Maniatis, T., E.F. Fritsch, and J. Sambrook. 1982. Molecular cloning. A laboratory manual. Cold Spring Harbor Laboratory, Cold Spring Harbor, New York.

McMullen, M.D., B. Hunter, R.L. Phillips, and I. Rubenstein. 1986. The structure of the maize ribosomal DNA spacer region. Nucleic Acids Res. 14: 4953-4968.

Meyuhas, O. 1984. Ribosomal protein gene expression in proliferating and nonproliferating cells. In Recombinant DNA and cell proliferation (ed. G. Stein and J. Stein), pp. 243-269. Academic Press, New York.

Mozer, T.J. 1980. Partial purification and characterization of the mRNA for a-amylase from barley aleurone layers. Plant Physiol. 65: 834-837.

Murashige, T. and F. Skoog. 1962. A revised medium for rapid growth and bioassays with tobacco tissue cultures. Physiol. Plant 15: 473-497.

Okayama, H. and P. Berg. 1982. High efficiency cloning of fulllength cDNA. Mol. Cell. Biol. 2: 161-170.

Phillips, R.L., A.S. Wang, and R.V. Kowles. 1983. Molecular and developmental cytogenetics of gene multiplicity in maize. Stadler Symp, 15: 105-118.

Phillips, R.L., R.V. Kowles, M.D. McMullen, S. Enomoto, and I. Rubenstein. 1985. Developmentally timed changes in maize endosperm DNA. In Plant genetics (ed. M. Freeling), pp. 739-754. Alan R. Liss, New York.

Pierandrei-Amaldi, P., N. Campioni, E. Beccari, I. Bozzoni, and F. Amaldi. 1982. Expression of ribosomal protein genes in Xenopus laevis development. Cell 30: 163-171.
Piko, L. and K.B. Clegg. 1982. Quantative changes in total RNA, total poly(A) and ribosomes in early mouse embryos. Dev. Biol. 89: 362-378.

Ramagopal, S. and H.L. Ennis. 1982. Ribosomal protein synthesis during spore germination and vegitative growth in Dictyostelium discoideum. I. Biol. Chem. 257: 1025-1031.

Rhoads, D.D. and D.J. Roufa. 1985. Emetine resistance in Chinese hamster cells: Structures of wild-type and mutant ribosomal protein S14 mRNAs. Mol. Cell. Biol. 5: 1655-1659.

Rhoads, D.D., A. Dixit, and D.J. Roufa. 1986. Primary structure of human ribosomal protein S14 and the gene that encodes it. Mol. Cell Biol. 6: 2774-2783.

Rigaud, G.F., T. Grange, and R. Pictet. 1987. The use of $\mathrm{NaOH}$ as transfer solution of DNA onto nylon membranes decreases the hybridization efficiency. Nucleic Acids Res. 15: 857 .

Rigby, P.W.J., M. Diekmann, C. Rhodes, and P. Berg. 1977. Labelling deoxyribonucleic acid to high specific activity in vitro by nick translation with DNA polymerase I. $J$. Mol. Biol. 113: 237-251.

Rubenstein, I. and D.E. Geraghty. 1986. The genetic organization of zein. In Advances in cereal science technology (ed. Y. Pomeranz), pp. 297-315. American Association of Cereal Chemists, St. Paul, Minnesota.

Sanger, F., S. Nicklen, and A.R. Coulson. 1977. DNA sequencing with chain terminating inhibitors. Proc. Natl. Acad. Sci. 69: 1408-1412.

Santon, J.B. and M. Pellegrini. 1980. Expression of ribosomal proteins during Drosophila early development. Proc. Natl. Acad. Sci. 77: 5649-5653.

Schloss, J.A., C.D. Silflow, and J.L. Rosenbaum. 1984. mRNA abundance changes during flagellar regeneration in Chlamydomonas reinhardtii. Mol. Cell. Biol. 4: 424-434.

Sheridan, W.F. 1975. Tissue culture of maize I. Callus induction and growth. Physiol. Plant. 33: 151-156.

- 1982. Black Mexican sweet corn: Its use for tissue cultures. In Maize for biological research (ed. W.F. Sheridan), pp. 385-388. University Press, Grand Forks, North Dakota.

Snustad, D.P., J.P. Hunsperger, B. Chereskin, and J. Messing. 1988. Maize glutamine synthetase cDNAs: Isolation by direct genetic selection in Escherichia coli. Genetics 120: $1111-1124$.

Soave, C. and F. Salamini. 1984. The role of structural and regulatory genes in the development of maize endosperm. Dev. Genet. 5: 1-25.

Southern, E.M. 1975. Detection of specific sequences among DNA fragments separated by gel electrophoresis. $J$. Mol. Biol. 98: 503-517.

Tushinski, R.J. and J.R. Warner. 1982. Ribosomal proteins are synthesized preferentially in cells commencing growth. $J$. Cell Physiol. 112: 128-135.

Vieira, J. and J. Messing. 1987. Production of single-stranded plasmid DNA. Methods Enzymol. 153: 3-11.

Wagner, M. and R.P. Perry. 1985. Characterization of the multigene family encoding the mouse S16 ribosomal protein: Strategy for distinguishing an expressed gene from its processed pseudogene counterparts by an analysis of total genomic DNA. Mol. Cell. Biol. 5: 3560-3576.

Wiedemann, L.M. and R.P. Perry. 1984. Characterization of the expressed gene and several processed pseudo genes for the mouse ribosomal protein L30 gene family. Mol. Cell. Biol. 4: 2518-2528.

Woolford, J.L., Jr., L.M. Hereford, and M. Rosbash. 1979. Isolation of cloned DNA sequences containing ribosomal protein genes from Saccharomyces cerevisiae. Cell 18: 1247-1259. 


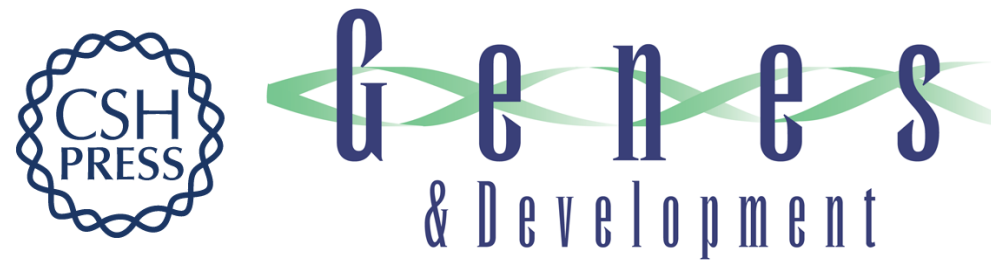

\section{The organization and expression of a maize ribosomal protein gene family.}

J C Larkin, J P Hunsperger, D Culley, et al.

Genes Dev. 1989, 3:

Access the most recent version at doi:10.1101/gad.3.4.500

References This article cites 53 articles, 21 of which can be accessed free at:

http://genesdev.cshlp.org/content/3/4/500.full.html\#ref-list-1

License

Email Alerting

Service

Receive free email alerts when new articles cite this article - sign up in the box at the top right corner of the article or click here.

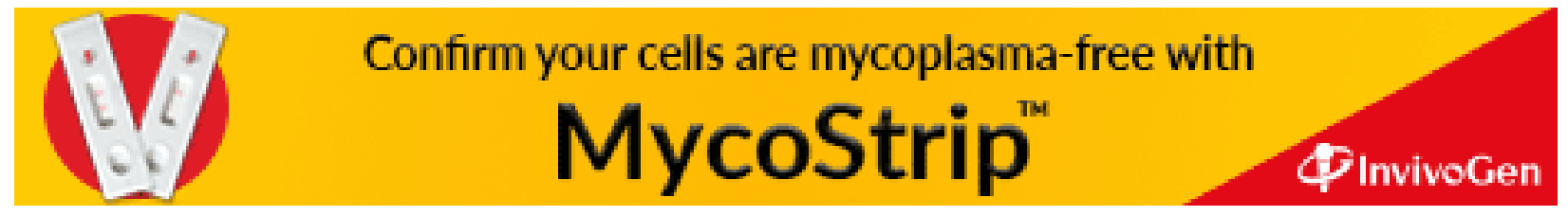

